\title{
Rola Trybunału Konstytucyjnego w procedurze impeachmentu w Korei Południowej
}

\footnotetext{
The role of the Constitutional Tribunal in the impeachment procedure in South Korea: The author describes the history and functioning of the Constitutional Tribunal of the Republic of Korea. The article also discusses the procedure of impeachment in the South Korean system since the adoption of the Constitution in 1948. The author focuses primarily on the development of Korean legislation regarding the above-mentioned impeachment procedure.
}

Keywords: Constitutional Tribunal, South Korea, impeachment, decision, president

Słowa kluczowe: Trybunał Konstytucyjny, Korea Południowa, impeachment, decyzja, prezydent

\section{Wstęp}

Instytucja impeachmentu wywodzi się z ustroju Anglii, w którym Izba Lordów m.in. sądziła sprawy karne $\mathrm{z}$ oskarżenia Izby Gmin ${ }^{1}$. Powstanie tej instytucji ustrojowej było wynikiem wzrostu znaczenia parlamentu w angielskim życiu politycznym ${ }^{2}$. Następnie została ona recypowana do Konstytucji Stanów Zjed-

1 Zob. A. Okolski, Ustrój państw europejskich i Stanów Zjednoczonych Ameryki Pótnocnej, Warszawa 1887, s. 42-43; W. Wilson, Ustrój państwowy Anglji, Warszawa 1917, s. 15 i n.; A. Peretiatkowicz, Państwo wspótczesne, Poznań 1947, s. 89; K. Koranyi, Powszechna historia państwa i prawa, t. IV, Warszawa 1967, s. 95-96; E. Gdulewicz, W. Kręcisz, Ustrój polityczny Wielkiej Brytanii [w:] E. Gdulewicz, W. Kręcisz, W. Skrzydło, W. Zakrzewski, Ustroje państw współczesnych, Lublin 1992, s. 8-9; P. Sarnecki, Ustroje konstytucyjne państw współczesnych, Warszawa 2013, s. 56 i n.

2 Szerzej zob. A. Esmein, Prawo konstytucyjne, Warszawa 1921, s. 111-114; K. Baran, Impeachment a początki odpowiedzialności politycznej ministrów w Anglii, „Zeszyty Naukowe Uniwersytetu Jagiellońskiego. Prace Prawnicze” 1971, z. 51; K. Baran, Dzieje 
noczonych z 1787 r. i znalazła praktyczne zastosowanie w ustroju tego państwa. Zgodnie z ustawą zasadniczą Stanów Zjednoczonych Izbie Reprezentantów przysługuje prawo pociągnięcia do odpowiedzialności konstytucyjnej prezydenta, wiceprezydenta i wyższych urzędników federalnych za zdradę stanu, przekupstwo oraz „inne ciężkie zbrodnie i przestępstwa”. Tego rodzaju sprawy rozpatrywane są przez Senat, a do wydania wyroku skazującego wymagana jest większość $2 / 3$ głosów obecnych senatorów ${ }^{3}$.

$\mathrm{Na}$ kontynencie europejskim rozwój odpowiedzialności władzy wykonawczej, czyli przede wszystkim ministrów, wprowadzony został we Francji po zmianach ustrojowych, zapoczątkowanych przez Wielką Rewolucję Francuską (1789 r.). W wieku XIX większość konstytucji przewidywała instytucje, które dotyczyły odpowiedzialności konstytucyjnej ministrów ${ }^{4}$. Co istotne, w tym okresie miała miejsce ewolucja rozwiązań instytucjonalnych, w zakresie odpowiedzialności konstytucyjnej, która polegała na powoływaniu do rozpatrywania deliktów konstytucyjnych specjalnie do tego powołanych, zwykle przez parlament, trybunałów ${ }^{5}$. W polskich realiach ustrojowych odpowiedzialność konstytucyjną ministrów wprowadziła Konstytucja 3 maja 1791 r., zgodnie z którą ponosili oni odpowiedzialność przed sądem sejmowym, złożonym z posłów i senatorów ${ }^{6}$. Później odpowiedzialność konstytucyjna osób sprawujących władzę wykonaw-

przestępstw politycznych $w$ Anglii między średniowieczem a współczesnością, Kraków 2000.

3 Zob. W. Wilson, Ustrój państwowy Stanów Zjednoczonych Ameryki Północnej, Warszawa 1917, s. 95 i n.; J. Makowski, Ustrój konstytucyjny Stanów Zjednoczonych Ameryki Pólnocnej, Warszawa 1918, s. 21; A. Peretiatkowicz, Państwo współczesne z dodatkiem: ustrój polityczny Stanów Zjednoczonych, Poznań 1920, s. 56; idem, Państwo współczesne, op. cit., s. 115-116; K. Koranyi, Powszechna historia państwa i prawa, t. IV, op. cit., s. 230; J. Jaskiernia, Zagadnienie podstaw do wszczęcia procedury impeachmentu, „Ruch Prawniczy, Ekonomiczny i Socjologiczny” 1975, nr 4; A. Makowski, Instytucja impeachment w Stanach Zjednoczonych, „Państwo i Prawo” 1975, z. 12; R.M. Małajny, Amerykański model odpowiedzialności konstytucyjnej, „Studia Prawnicze” 1990, nr 3; W. Zakrzewski, Ustrój polityczny Stanów Zjednoczonych Ameryki [w:] E. Gdulewicz, W. Kręcisz, W. Skrzydło, W. Zakrzewski, Ustroje państw współczesnych, Lublin 1992, s. 188 i n.; A. Kulig, Stany Zjednoczone Ameryki [w:] Systemy ustrojowe państw współczesnych, red. S. Bożyk, M. Grzybowski, Białystok 2012, s. 68 i n.; P. Sarnecki, Ustroje konstytucyjne, op. cit., s. 132-133; R. Piotrowski, Senat Stanów Zjednoczonych Ameryki. Struktura i funkcje, Warszawa 2013, s. 280-290.

4 Zob. Z. Szcząska, Odpowiedzialność prawna ministrów w państwach konstytucyjnych XVIII-XIX wieku [w:] Wiek XVIII. Polska i świat. Księga poświęcona Bogusławowi Leśnodorskiemu, Warszawa 1974.

5 Szerzej zob. M. Pietrzak, Odpowiedzialność konstytucyjna w Polsce, Warszawa 1992, s. $42 \mathrm{i} \mathrm{n.}$

6 Szerzej zob. Z. Szcząska, Odpowiedzialność rządu w Polsce w latach 1775-1792, „Czasopismo Prawno-Historyczne" 1975, t. XXVII, nr 1. 
czą była przewidziana w Konstytucji Księstwa Warszawskiego z 22 lipca 1807 r. oraz Królestwa Polskiego z 27 listopada 1815 r. W okresie II Rzeczypospolitej zarówno Konstytucja z 17 marca 1921 r., jak i z 23 kwietnia 1935 r. powierzały wykonywanie odpowiedzialności konstytucyjnej specjalnie powołanemu do tego Trybunałowi Stanu ${ }^{7}$. Po zakończeniu drugiej wojny światowej dopiero znowelizowana w 1982 r. Konstytucja Polskiej Rzeczypospolitej Ludowej z 22 lipca 1952 r. wprowadziła odpowiedzialność konstytucyjną przedstawicieli władzy wykonawczej przed Trybunałem Stanu, co było związane z ówczesnym kryzysem gospodarczym ${ }^{8}$. Współcześnie Trybunał Stanu jest przewidziany w Konstytucji z 2 kwietnia 1997 r. .

Termin „impeachment”, według Aleksandra Makowskiego i Longina Pastusiaka, pochodzi od łacińskiego imperdicare, co oznacza „zapobiegać, utrudniać". W praktyce parlamentarnej państw, w których instytucja impeachmentu była lub jest nadal używana, oznacza on po prostu „oskarżenie” lub „zarzut”10. Z kolej Bogusław Banaszak uznał, że impeachment jest: [s]zczególnym rodzajem odpowiedzialności prawnej osób zajmujących stanowiska państwowe w krajach anglosaskich i tych, które z nich czerpały wzory ustrojowe (wiele krajów Ameryki Łacińskiej, kraje Commonwealthu, Ukraina, gdzie konstytucja z 1996 r. w art. 111 używa tego terminu) ${ }^{11}$. Andrzej Pułło natomiast zdefiniował impeachment jako procedurę, która polega na stawianiu osób zajmujący ważne stanowiska państwowe w stan oskarżenia przez jedną z izb parlamentu, a sądzeniu przez drugą ${ }^{12}$.

Impeachment w ustroju Korei Południowej, w porównaniu np. z amerykańskim, charakteryzuje się specyficzną praktyką. Instytucja ta w Korei stanowi oskarżenie przeciwko politykom, sędziom, urzędnikom, którzy w czasie spra-

7 Szerzej zob. W. Komarnicki, Polskie prawo polityczne. Geneza i system, Warszawa 1922; idem, Ustrój państwowy Polski współczesnej. Geneza i system, Wilno 1937.

8 Szerzej zob. A. Gubiński, Trybunał Stanu, „Państwo i Prawo” 1982, z. 5-6; L. Garlicki, Charakter ustrojowy nowych trybunałów, „Państwo i Prawo” 1986, z. 3; Trybunał Stanu w PRL, red. Z. Świda-Łagiewska, Warszawa 1983; M. Pietrzak, Odpowiedzialność konstytucyjna, op. cit., s. 132 i n.

9 Szerzej zob.: Z. Szeliga, Odpowiedzialność parlamentarzystów, Prezydenta, Rady Ministrów oraz jej członków w świetle Konstytucji RP z 2 kwietnia 1997 roku, Lublin 2003; J. Zaleśny, Odpowiedzialność konstytucyjna w prawie polskim okresu transformacji ustrojowej, Toruń 2004; idem, Odpowiedzialność konstytucyjna. Praktyka III RP, Warszawa 2004; M. Kowalska, Odpowiedzialność członków egzekutywy przed Trybunałem Stanu w III Rzeczypospolitej Polskiej, Lublin 2018.

10 Zob. A. Makowski, L. Pastusiak, Impeachment o usuwaniu polityków z urzędu, Warszawa 1999, s. 9.

11 B. Banaszak, Porównawcze prawo konstytucyjne współczesnych państw, Warszawa 2007 s. 340.

12 Konstytucja Stanów Zjednoczonych Ameryki, tłum. i wstęp A. Pułło, Warszawa 2002, s. 40 . 
wowania swoich funkcji nie przestrzegali konstytucji bądź ustaw. W Korei zastosowano zasadę, że Zgromadzenie Narodowe ${ }^{13}$, w praktyce parlamentarzyści, formułują jedynie akt oskarżenia na podstawie art. 65 ust. 2 Konstytucji Korei Południowej ${ }^{14}$, a Trybunał Konstytucyjny rozstrzyga taką sprawę na podstawie art. 111 i na podstawie art. 2 ustawy o Trybunale Konstytucyjnym ${ }^{15}$. W Stanach Zjednoczonych funkcję sądowniczą w praktyce impeachmentu pełni Senat. Trybunał Konstytucyjny Republiki Korei ${ }^{16}$ zaczął funkcjonować od 1988 r., co było związane z nowelizacją Konstytucji z 1987 r. ${ }^{17}$. Stało się to w wyniku ruchów społecznych obywateli, którzy domagali się zmian demokratycznych, gdyż w Korei panowała dyktatura wojskowa oraz ustrój autorytarny ${ }^{18}$. Od tego momentu Trybunał, jako część organu władzy sądowniczej ${ }^{19}$ oraz jako organ konstytucyjny, stanął na straży ochrony konstytucji i wydawania orzeczeń związanych z ustawą zasadniczą ${ }^{20}$.

Działalność Trybunału Konstytucyjnego reguluje Konstytucja Republiki Korei (od art. 111 do art. 113) ) $^{11}$ oraz ustawa o Trybunale Konstytucyjnym. Ponadto organizację i wewnętrzne funkcjonowanie normuje wewnętrzny regulamin Trybunału, w szczególności dotyczy on rozpraw konstytucyjnych ${ }^{22}$. Zgodnie z art. 111 Konstytucji Korei Trybunał orzeka w sprawach:

- konstytucyjność prawa, na wniosek sądów (dotyczy tu w szczególności zbadania zgodności ustaw z konstytucją),

- odpowiedzialności konstytucyjnej (chodzi tu głównie właśnie o procedurę impeachmentu),

- rozwiązania partii politycznej,

13 Zob. J. Sułkowski, Parlament Korei Południowej, Warszawa 2014. W Korei parlament jest jednoizbowy i nosi nazwę Zgromadzenia Narodowego.

14 Przepis ten właśnie daje możliwość członkom parlamentu wnieść skargę impeachmentu do Trybunału Konstytucyjnego.

15 Ustawa nr 15495 z 20 marca 2018 r., z częściową zmianą (tekst jednolity), 법률 제 15495호, 2018.3.20., 일부개정.

16 Jest to oficjalna nazwa Korei Południowej.

17 O Trybunale Konstytucyjnym po raz pierwszy stanowiła Konstytucja nr 4 z 15 czerwca 1960 r. Jednakże po wejściu w życie tej Konstytucji, z powodu wybuchu puczu wojskowego 16 maja 1961 r., Trybunał Konstytucyjny ani razu nie orzekał. Zob. Komentarz do Konstytucji, cz. III, Seul 2010 s. 350-352, 헌법주석 III, 350-352페이지, 서울2010.

18 Szerzej na ten temat: W.J. Dziak, G. Strnad, Republika Korei. Zarys ewolucji systemu politycznego, Warszawa 2011.

19 Sam Trybunał ustalił to w swojej decyzji z 31 sierpnia 1994 r., sygn. 92 Heonma 126 (92헌마126).

20 W Korei ostateczne orzeczenie Trybunału nie jest nazwane „wyrokiem”, ale „decyzją?.

${ }^{21}$ Konstytucja $\mathrm{nr} 10 \mathrm{z} 29$ października 1987 r., z całkowitą nowelizacją, 헌법 제10호, 1987. 6. 29., 전부개정.

22 Zasada Trybunału Konstytucyjnego nr 324 z 9 czerwca 2014 r. 
- sporów kompetencyjnych między organami państwa, między organami państwa a samorządami lokalnymi, a także między samorządami lokalnymi,

- skargi konstytucyjnej na zasadach określonych w ustawie ${ }^{23}$.

Artykuł 2 ustawy o Trybunale Konstytucyjnym powtarza unormowania zawarte w konstytucji. Na podstawie art. 111 ust. 2 konstytucji i art. 3 ustawy o Trybunale Konstytucyjnym skład Trybunału liczy 9 sędziów. Trzech powołuje prezydent, kolejnych trzech sędziów powołuje Zgromadzenie Narodowe, czyli parlament, a trzech - Prezes Sądu Najwyższego ${ }^{24}$.

\section{Zarys procedury impeachmentu w Republice Korei ${ }^{25}$}

W Korei dotychczas dziewięciokrotnie nowelizowano konstytucję od jej wejścia w życie w 1948 r. Wszystkie teksty tzw. konstytucji, które zostaną omówione, nie są nowo uchwalonymi ustawami zasadniczymi, lecz nowelizacjami konstytucji z 1948 r. W preambule obecnej konstytucji określono, że ustawa zasadnicza po 1948 r. została zmieniona ośmiokrotnie. Licząc nowelizację obecnej konstytucji z 1987r., należy stwierdzić, że konstytucja Korei Południowej w sumie była zmieniona dziewięciokrotnie po jej wejściu w życie ${ }^{26}$. Należy dodać, że w historii prawa ustrojowego Korei wyróżnia się tzw. sześć republik27. Zmiany ustawy zasadniczej było związane z powstaniem kolejnej republiki i zmianą ustroju państwa, np. z ustroju demokratycznego na autorytarny albo odwrotnie ${ }^{28}$. Jednak nie wszystkie nowele konstytucji powodowały powstanie nowej republiki, gdyż niektóre dotyczyły tylko zmiany kilku przepisów (np. zmiana kadencji prezydenta), a nie zmiany ustroju państwa koreańskiego ${ }^{29}$. Większa część nowelizacji konstytucji dotyczyła różnych zasad procedury impeachmentu. Jednak w praktyce często nie powoływano Trybunału Konstytucyjnego jako właściwego organu do rozstrzygnięcia procedury impeachmentu.

Istotne znaczenie ma przedstawienie genezy ewolucji postępowania przed Trybunałem. Na podstawie art. 46 konstytucji z $1948 \mathrm{r}^{30}$, jeśli w czasie pełnienia

23 Na podstawie tłumaczenia: Konstytucja Republiki Korei, przekład z języka koreańskiego A. Diniejko, wprowadzenie i konsultacja merytoryczna M.M. Wiszowaty, Gdańsk 2015.

24 Jest to odpowiednik I Prezesa Sądu Najwyższego w Polsce.

25 Szerzej zob. Komentarz do Konstytucji, op. cit.

26 Zob. Konstytucja Republiki Korei, op. cit.

${ }_{27}$ Obecnie w Korei jest VI republika ze względu na zmianę Konstytucji w 1987 r.

28 Tak było w roku 1960 i 1987. Zob. G. Strnad, Południowokoreańska droga do demokracji, Toruń 2010.

29 Szerzej zob. S. Choi, Władza wykonawcza w Republice Korei, Warszawa 2018.

30 Konstytucja nr 1 z 17 lipca 1948 r., uchwalona, 헌법 제1호, 1948. 7. 17., 재정. W tym dniu ogłoszono Konstytucję. Porównując z Polską w Korei istotna jest data ogłoszenia 
obowiązków prezydent, wiceprezydent, premier, członkowie Rady Państwa (chodzi o ministrów), prezes organu kontroli finansowej rządu ${ }^{31}$, sędzia oraz urzędnik nie przestrzegał konstytucji bądź ustawy, mógł być oskarżony przez parlament. Wniosek mogło składać co najmniej 50 posłów Zgromadzenia Narodowego ${ }^{32}$. Zgodę natomiast wyrażało $2 / 3$ posłów w obecności $2 / 3$ składu parlamentu. Sprawa toczyła się w tzw. Trybunale Impeachmentu. Funkcję sędziego przewodniczącego pełnił wiceprezydent, a w składzie było 5 sędziów Sądu Najwyższego, 5 posłów Zgromadzenia Narodowego. Jednak, kiedy skarga była kierowana przeciwko prezydentowi i wiceprezydentowi, to Prezes Sądu Najwyższego pełnił funkcję sędziego przewodniczącego. Do usunięcia określonej osoby potrzeba było zgody $2 / 3$ składu sędziowskiego. Wyrok impeachmentu powodował zwolnienie osoby z pełnionego urzędu, przy czym konstytucja stanowiła, że nie zwalniało to określonej osoby od odpowiedzialności cywilnej i karnej (art. 47).

Zgodnie z art. 46 znowelizowanej konstytucji w $1952 \mathrm{r}^{33}$ parlament stał się dwuizbowy, skarga dotycząca impeachmentu powinna być wniesiona przynajmniej przez 50 posłów izby niższej ${ }^{34}$. Skarga była przekazywana do Trybunału Impeachmentu ${ }^{35}$. W znowelizowanej konstytucji z $1954 \mathrm{r}^{36}$ nie było zmiany procedury impeachmentu. Z kolei w konstytucji z $1960 \mathrm{r}^{37}$ po raz pierwszy w historii Korei powstał Trybunał Konstytucyjny w składzie 9 sędziów. Skarga impeachmentu była, zgodnie $\mathrm{z}$ art. $83^{3} \mathrm{i} \mathrm{z}$ art. $83^{4}$, rozpatrywana przez Trybunał w składzie 9 sędziów wybranych po trzech: przez prezydenta, Sąd Najwyższy oraz izbę wyższą parlamentu ${ }^{38}$. W znowelizowanej konstytucji ${ }^{39}$ dodano, że sę-

ustawy zasadniczej, w Polsce ważniejszy jest dzień uchwalenia. Jest też to pierwsza konstytucja z czasu, kiedy powstał pierwszy parlament w Korei. Dlatego 17 lipca jest Świętem Konstytucji w Korei Południowej. Ponadto porównując z Polską w Korei datę pisze się kolejno: od roku, miesiąca, a potem dzień.

31 Można uznać, że ten organ był odpowiednikiem Najwyższej Izby Kontroli w obecnej Polsce. Jednak jego funkcja była ograniczona do zakresu kontroli finansowej rządu w Korei Południowej.

32 Parlament w Korei był wtedy jednoizbowy. Dlatego nazywał się Zgromadzeniem Narodowym.

33 Konstytucja nr 2 z 7 lipca 1952 r., z częściową zmianą, 헌법 제2호, 1987. 6. 29., 일부 개정.

34 W jęz. koreańskim 민의 원, czyta się Mineuiwon.

35 Jeżeli chodzi o skład Trybunału, to nie uległ on zmianie.

36 Konstytucja nr 3 z 29 listopada 1954 r., z częściową zmianą, 헌법 제3호, 1954. 11. 29., 일부개정.

37 Konstytucja nr 4 z 15 czerwca 1960 r., z częściową zmianą, 헌 법 제4호, 1960. 6. 15., 일부개정.

${ }^{38}$ W jęz. koreańskim 참의 원 czyta się Chameuiwon. W Korei parlament był wtedy dwuizbowy.

39 Konstytucja nr 5 z 29 listopada 1960 r., z częściową zmianą, 헌 법 제5호, 1960. 11. 29., 일부개정. 
dzia Trybunału Konstytucyjnego też mógł być oskarżony w procedurze impeachmentu. Impeachment, na podstawie art. 46 ust. 2 tej konstytucji, mógł być wniesiony z inicjatywy co najmniej 30 posłów izby niższej, a uchwalony za zgodą więcej niż połowy głosów członków obu izb parlamentu. W tym samym roku znowelizowano konstytucję, przy czym zmiana ta nie dotyczyła procedury impeachmentu.

Zgodnie z kolejną nowelizacją konstytucji w $1962 \mathrm{rr}^{40}$ został wykluczony organ kontroli finansowej rządu, a przepis o Trybunale Konstytucyjnym został usunięty. Była to konstytucja nowelizowana w duchu autorytaryzmu przez koła wojskowe, które dokonały puczu wojskowego w roku $1961^{41}$. W znowelizowanej konstytucji dodano, że członek Centralnej Komisji Wyborczej może być oskarżony, jeśli nie przestrzega konstytucji lub ustawy. Inicjatywa rozpoczęcia impeachmentu należała do 30 posłów Zgromadzenia Narodowego ${ }^{42}$, za zgodą więcej niż połowy członków Zgromadzenia Narodowego. Sprawę badała Komisja Impeachmentu w składzie: trzech sędziów Sądu Najwyższego, pięciu posłów Zgromadzenia Narodowego. Na czele Trybunału stał Prezes Sądu Najwyższego, przy czym jeśli był sądzony Prezes Sądu Najwyższego, to na czele Komisji stał przewodniczący (Speaker) Zgromadzenia Narodowego ${ }^{43}$. Za przyjęciem skargi musiało opowiedzieć się co najmniej 6 członków Komisji.

W znowelizowanej w roku 1969 konstytucji ${ }^{44}$ nie wprowadzono prawie żadnych zmian, z wyjątkiem zmiany liczby głosów do uchwalenia impeachmentu. Impeachment przeciwko prezydentowi mogło zainicjować co najmniej 50 posłów Zgromadzenia Narodowego, a do jego uchwalenia potrzeba było zgody 2/3 głosów członków Zgromadzenia Narodowego. Zgodnie z kolejną nowelizacją konstytucji z 1972 r. ${ }^{45}$, w rozdziale VIII, powołano Komisję Konstytucyjną. Urzędnicy wymienieni w art. 99 konstytucji mogli być oskarżeni z inicjatywy $1 / 3$ głosów posłów parlamentu, a do uchwalenia musiała być zgoda więcej niż połowy członków Zgromadzenia Narodowego. W przypadku oskarżenia prezydenta inicjatywa powinna pochodzić od więcej niż połowy posłów Zgromadzenia Narodowego. Sprawa toczyła się w Komisji Konstytucyjnej, w której składzie było 9 członków, w tym trzech mianowanych przez prezydenta, trzech powołanych przez Zgromadzenie Narodowe, trzech powołanych przez Prezesa Sądu Najwyż-

40 Konstytucja nr 6 z 26 grudnia 1962 r., z całkowitą nowelizacją, 헌법 제6호, 1962. 12. 26., 전부개정.

41 Pucz wybuchł 16 maja 1961 r. Zob. G. Strnad, Południowokoreańska droga, op. cit.

42 W tym okresie parlament koreański był znów jednoizbowy.

43 Można uznać, że odpowiada on Marszałkowi Sejmu w Polsce.

44 Konstytucja nr 7 z 21 listopada 1969 r., z częściową zmianą, 헌 법 제7호, 1969. 11.21., 일부개정.

45 Konstytucja nr 8 z 27 grudnia 1972 r., z całkowitą nowelizacją, 헌법 제8호, 1972. 11. 29., 전부개정. 
szego. Z kolei w nowelizacji konstytucji z $1980 \mathrm{r}^{46}{ }^{4}$ nie było prawie zmiany ${ }^{47}$, jeżeli chodzi o procedurę impeachmentu, jednak znalazł się przepis, który stanowił, że nawet, gdy to prezydent został odwołany w wyniku impeachmentu, to nie zwalniało go to od odpowiedzialności cywilnej ani karnej.

\section{Procedura impeachmentu po nowelizacji konstytucji w 1987 r.}

Zasady procedury impeachmentu są skomplikowane i należą do trudnych zagadnień konstytucyjnych Korei Południowej. W praktyce ustrojowej Korei dwa razy miała miejsce procedura impeachmentu przeciwko prezydentowi. Było to w 2004 r. oraz w 2016 r. W państwie koreańskim odpowiedzialność prawną ponoszą podmioty wymienione w art. 65 ust. 1 obecnej konstytucji. Odpowiedzialność konstytucyjną bądź ustawową ponoszą: prezydent, premier, członek Rady Państwa $^{48}$ (chodzi tu o ministrów), szefowie resortów wykonawczych, sędzia Trybunału Konstytucyjnego, członek Centralnej Komisji Wyborczej ${ }^{49}$, prezes i członkowie Komisji Audytu i Kontroli ${ }^{50}$ i inni urzędnicy określeni przez ustawę, np. prokurator, o którym stanowi art. 37 ustawy o prokuratorze ${ }^{51}$.

Zgodnie $\mathrm{z}$ art. 65 ust. 2 konstytucji, jeśli wymienione wyżej podmioty nie przestrzegają konstytucji lub ustawy, to Zgromadzenie Narodowe może wnieść skargę o pociągnięcie ich do odpowiedzialności konstytucyjnej, a inicjatywa w tej materii należy do 1/3 posłów. Obecnie, tzn. według stanu prawnego na 2019 r., w Zgromadzeniu Narodowym Korei jest 300 mandatów, na podstawie art. 21 ustawy o wyborze funkcjonariuszy publicznych ${ }^{52}$. W związku z tym inicjatywa należy do co najmniej 100 posłów. Za przyjęciem tej inicjatywy powinna głosować więcej niż połowa posłów, czyli co najmniej 151 członków Zgromadzenia Narodowego. Natomiast wyjątek stanowi proces impeachmentu przeciwko prezydentowi. Otóż inicjatywa taka powinna być zgłoszona przez więcej niż połowę posłów, czyli co najmniej 151 posłów, a zgodę na to powinno wyrazić swoimi głosami $2 / 3$ posłów, oznacza to, że powinna być to zgoda co najmniej 200 członków parlamentu.

46 Konstytucja nr 9 z 27 października 1980 r., z całkowitą zmianą, 헌 법 제9호, 1980. 10. 27., 전부개정.

47 Jedyną zmianą było to, że przepisy o Komisji Konstytucyjnej znalazły się w rozdziale VI, a nie VIII.

48 Jest to odpowiednik Rady Ministrów w Polsce.

49 Jest to odpowiednik Państwowej Komisji Wyborczej w Polsce.

50 Odpowiednikiem jest Najwyższa Izba Kontroli w Polsce.

51 Ustawa nr 15522 z 20 marca 2018 r., zmieniona przez inną ustawę, 법률 제 15522호, 2018. 3. 20., 타법개정.

52 Ustawa nr 15551 z 6 kwietnia 2018 r., z częściową zmianą, 법률 제15551호, 2018. 4. 6., 일부개정. 
Zasady głosowania szczegółowo reguluje art. 130 ustawy o Zgromadzeniu Narodowym ${ }^{53}$. Ustęp 1 tego artykułu stanowi, że po wniesieniu skargi impeachmentu to przewodniczący raportuje o tym na głównym spotkaniu posłów. Następnie z obrad Zgromadzenia Narodowego sprawa jest przekazywana do Komisji Sprawiedliwości. Ustęp 2 artykułu stanowi, że jeżeli w obradach nie postanowiono wysyłać skargi do Komisji Sprawiedliwości, to po 24 godzinach, a w ciągu 72 godzin parlament powinien głosować w sprawie tej skargi. Jeżeli w tym czasie głosowanie się nie odbędzie, to skarga automatycznie zostaje usunięta. Wreszcie ust. 3 artykułu określa, że w skardze powinny być podane: nazwisko i imię stanowisko podmiotu oskarżonego, następnie - przyczyny skargi. W załączniku powinny znaleźć się określone dowody oraz przedstawione materiały. Należy dodać, że przewodniczący Komisji Sprawiedliwości parlamentu jest oskarżycielem $^{55}$. W myśl art. 65 ust. 3 konstytucji dopóki nie nastąpi wydanie decyzji przez Trybunał Konstytucyjny w sprawie impeachmentu, to sprawujący urząd zostaje zawieszony w swoich funkcjach, o czym stanowi także art. 50 ustawy o Trybunale Konstytucyjnym. Decyzja orzekająca o odpowiedzialności konstytucyjnej może przewidywać usunięcie z urzędu, co nie oznacza, że określona osoba nie podlega odpowiedzialności cywilnej lub karnej (art. 65 ust. 4 konstytucji).

Wpływ skargi do Trybunału powoduje, że organ przyjmuje sprawę do swojej kognicji. Rozprawa musi być rozpatrzona w składzie co najmniej 7 sędziów (art. 23 ustawy o Trybunale Konstytucyjnym) ${ }^{56}$. Jeżeli jednak będzie mniej niż 7 sędziów, to procedura może być przerwana. Procedura jest wznowiona dopiero wtedy, gdy będzie powołany nowy sędzia Trybunału. Za przyjęciem skargi powinno się opowiedzieć co najmniej 6 sędziów, tzn. jeżeli co najmniej 6 sędziów nie opowie się za przyjęciem skargi, to zostaje ona odrzucona. Organ ten ma 180 dni na wydanie decyzji (art. 38 ustawy o Trybunale Konstytucyjnym). Rozprawa impeachmentu ma charakter postępowania karnego (art. 40 ust. 1 ustawy o Trybunale Konstytucyjnym). Stosuje się też w stosunku do sędziów zasady: iudex inhabilis (art. 24 ust. 1) oraz iudex suspectus (art. 24 ust. 3). W powyższych sytuacjach powołano zasadę postępowania cywilnego. W tym czasie Trybunał podczas rozpraw przesłuchuje strony oraz świadków w danej sprawie. Ostatecznie po zakończeniu czynności procesowych Trybunał wydaje decyzję. W decyzji powinny być zamieszczone: sygnatura sprawy, skarżący, oskarżony, data wydania decyzji,

53 Ustawa nr 15713 z 17 lipca 2018 r., z częściową zmianą, 법률 제15713호, 2018. 7. 17., 일부개정.

${ }^{54}$ W Korei najpierw zapisuje się nazwiska, a potem imiona.

55 Zazwyczaj w czasie procedury pomagają mu zawodowi prawnicy. Należy też dodać, że przewodniczącym komisji zostaje najczęściej poseł, który jest prawnikiem.

56 W czasie rozprawy impeachmentu prezydent Park Geun-Hye (między grudniem 2016 r. a marcem 2017 r.) kończyła się kadencja Prezesa Trybunału Konstytucyjnego (w dniu 31 stycznia 2017 r.). Wtedy Trybunał był zmuszony prowadzić rozprawę w składzie 8-osobowym. 
sentencja oraz uzasadnienie. Jednak w praktyce, gdy Trybunał ogłasza decyzję, to czyta najpierw uzasadnienie, a następnie sentencję. Trybunał oddala skargę albo przyjmuje skargę do rozpatrzenia. Kiedy Trybunał oddala skargę, to oskarżona osoba powraca na pełniony uprzednio urząd. Jeżeli Trybunał uznał skargę za zasadną, to osoba, wobec której toczy się postępowanie, zostaje usunięta $\mathrm{z}$ urzędu. Decyzja Trybunału ma tylko wpływ na usunięcie z urzędu danej osoby, co jednak nie wyłącza jej odpowiedzialności cywilnej czy karnej (art. 65 ust. 4 konstytucji).

\section{Impeachment w praktyce ustrojowej}

\section{Sprawa 2004 Heona ${ }^{57}$ (2004헌나1), czyli impeachment wobec prezydenta Roh Mu Hyeon}

Jak już wspomniano, w Korei Południowej dwa razy była rozpoczynana procedura impeachmentu przeciwko prezydentowi. Adresatem skargi była tylko głowa państwa, przeciwko innym podmiotom rządowym (np. premierowi czy ministrowi) lub też innym wysokim urzędnikom jeszcze nigdy nie była stosowana. Dlatego instytucja impeachmentu w praktyce ustrojowej była ograniczona tylko do głowy państwa i, co za tym idzie, miała istotny wpływ na konstytucjonalizm koreański oraz doktrynę prawa konstytucyjnego.

Pierwszy raz impeachment dotyczył prezydenta Roh Mu Hyeon (1946-2009) i miał miejsce w $2004 \mathrm{r}^{58}$. Był to pierwszy impeachment w historii konstytucjonalizmu Korei Południowej. Do 2004 r. pozycja Trybunału Konstytucyjnego wśród obywateli była mało znana. Na wstępie warto przedstawić, w sposób syntetyczny, stan faktyczny. Impeachment dotyczący głowy państwa został oparty, po pierwsze, na oskarżeniu, że prezydent Roh nie przestrzegał neutralności jako urzędnik, popierając konkretną partię przed wyborami parlamentarnymi. Prezydent Korei Południowej w lutym 2004 r., czyli dwa miesiące przed kampanią wyborczą ${ }^{59}$, podczas spotkania $\mathrm{z}$ dziennikarzami, prosił wyborców o poparcie dla partii, do której należał. Z tego powodu prezydent dostał „ostrzeżenie” od Centralnej Komisji Wyborczej, przy czym posłowie uznali, że prezydent, jako urzędnik, nie przestrzegał neutralności politycznej.

Po drugie, w czasie wyborów prezydenckich ludzie z obozu politycznego kandydata Roh Mu Hyeon (Roh był wtedy jeszcze kandydatem na prezydenta) otrzymali korzyści majątkowe (łapówki) od znanych koncernów koreańskich i z tego powodu zostali oni aresztowani przez prokuraturę. Posłowie, którzy oskarżali prezydenta, uznali, że do tej sytuacji doprowadził też sam prezydent.

\footnotetext{
57 „Heona” jest sygnaturą spraw do impeachmentu.

$58 \quad$ Http://www.koreaherald.com/view.php?ud=20161208000727.

59 W Korei wybory parlamentarne odbywają się w kwietniu.
} 
Ponadto prezydent prowadził źle ocenianą przez parlament politykę gospodarczą. W związku z tym kraj ogarnął kryzys ekonomiczny w okresie, kiedy poziom gospodarczy na świecie (według stanu z 2003 r.) był wysoki. Po czwarte, zarzucano głowie państwa, że jako prezydent i szef rządu w nienależyty sposób pełnił swoje obowiązki konstytucyjne i polityczne. Zgromadzenie Narodowe oceniło, że prezydent niestarannie pełnił swoją funkcję i nie wykonywał należycie swoich obowiązków.

W dniu 12 marca 2004 r. Zgromadzenie Narodowe Republiki Korei w XVI kadencji uchwaliło impeachment wobec prezydenta Roh Mu Hyeon 193 głosa$\mathrm{mi}^{60}$. Sprawę następnie przekazano do Trybunału Konstytucyjnego. Oczywiście prezydent Roh nie mógł urzędować, ponieważ wszystkie jego prawa zostały zawieszone. Trybunał po rozpoznaniu sprawy wydał decyzję w dniu 12 maja $2004 \mathrm{r}$. Organ ten oddalił skargę z następujących powodów. Po pierwsze, Trybunał ocenił, że prośba prezydenta o poparcie konkretnej partii była niezgodna z przepisem prawa wyborczego, jednak stwierdzono, iż prezydent nie mówił tu o poparciu konkretnego kandydata na posła w celu jego dyskwalifikacji bądź też zwycięstwa w wyborach. Poza tym Trybunał stwierdził, że wybór posła do parlamentu ma większe znaczenie niż poparcie konkretnej organizacji politycznej. Po drugie, Trybunał oddalił skargę z tego powodu, że afera korupcyjna wydarzyła się nie w czasie kadencji prezydenta, tylko przed rozpoczęciem jego kadencji. Należy to interpretować $\mathrm{w}$ ten sposób, że oskarżenie przeciwko prezydentowi wnosi się jedynie z powodu nieprzestrzegania prawa w czasie jego kadencji ${ }^{61}$. Po trzecie, Trybunał ocenił, że prezydent nie odpowiada politycznie ${ }^{62}$, co należy do specyfiki systemu prezydenckiego ${ }^{63}$. Dlatego prezydent nie może być odwołany i odpowiadać z tego powodu, że jego polityka negatywnie wpływa na rozwój gospodarczy kraju. W związku z tym prezydent ponosi konsekwencję jedynie za to, że nie przestrzega prawa. $Z$ tych przyczyn Trybunał uznał skargę za nieuzasadnioną. Ponadto Trybunał stwierdził, że trudno wskazać skalę starannego wykonywania urzędu i także w tym zakresie postanowił oddalić skargę. Ostatecznie prezydent Roh Mu Hyeon powrócił na zajmowane stanowisko i zakończył kadencję w lutym $2008 \mathrm{r}^{64}$.

$\mathrm{W}$ podsumowaniu należy stwierdzić, że Trybunał odegrał w tej sprawie istotną rolę. Nie tylko wydał pierwszą decyzję w sprawie impeachmentu, ale zdefiniował

60 Zob. https://terms.naver.com/entry.nhn?docId=5570534\&cid=60379\&categoryId=60387.

${ }_{61}$ O tym też wyraźnie stanowi art. 65 Konstytucji, o którym wspomniano na początku artykułu.

${ }^{62}$ O odpowiedzialności politycznej prezydenta zob. S. Choi, Władza wykonawcza, op. cit., s. 39.

${ }^{63}$ Cechy systemu prezydenckiego zob. S. Sagan, V. Serzhanova, Nauka o państwie wspótczesnym, Warszawa 2013, s. 139.

64 Kadencja prezydenta w Korei wynosi 5 lat i nie może on być ponownie wybrany na ten sam urząd (art. 70 Konstytucji Korei Południowej). W przypadku prezydenta Roh było tak, że rozpoczął on kadencję w lutym 2003 r. 
pojęcia prawne, takie jak np. urzędnik państwowy, w tym wyjaśnił zagadnienia: czy prezydent jest także takim urzędnikiem oraz czy i jakie czynności prezydenta podlegają procedurze impeachmentu ${ }^{65}$. Omówiona, w dużym skrócie, decyzja Trybunału stała się wzorem dla wielu następnych orzeczeń. Należy podkreślić, że w uzasadnieniu decyzji „2016 Heonal” (jest to sprawa impeachmentu prezydent Park Geun-Hye) wielokrotnie odwołano do omawianego rozstrzygnięcia.

\section{Sprawa 2016 Heona1 (2016헌나1), czyli impeachment wobec prezydent Park Geun-Hye}

Po 12 latach Trybunał Konstytucyjny musiał rozpatrzyć kolejną sprawą z zakresu impeachmentu. Była to sprawa prezydent Park Geun-Hye ${ }^{66}$. Stan faktyczny był następujący. W październiku 2016 r. stacja telewizyjna Jtbc ogłosiła ${ }^{67}$, że na tablecie osoby, która nazywała się Choi Soon Shil (rzeczywiście nazywała się ona Choi Seo Won) zapisano dokumenty z pałacu prezydenckiego, w tym przemowę pani prezydent. Osoba ta była znana z tego, że była znajomą pani prezydent. Nie była ona żadną urzędniczką, tylko zwykłą obywatelką Korei Południowej. Warto zaznaczyć, że osoba fizyczna, niebędąca urzędnikiem, nie miała prawa wynosić dokumentów państwowych z pałacu prezydenckiego na zewnątrz.

Obywatele byli zaskoczeni, ponieważ ujawniono, że osoba ta poprawiła przemówienie pani prezydent i dodała niektóre zdania, a to z kolei oznaczało, że słowa prezydenta były tak naprawdę jej słowami. Wreszcie ujawniono, że miała ona istotny wpływ na politykę państwa. W tym samym czasie wyszła na jaw inna głośna sprawa. Prezydent Park założyła fundację sportową, korzystając z pieniędzy koncernów koreańskich. Po tych wydarzeniach obywatele mieli dość powodów, aby protestować, żądając jednocześnie dymisji głowy państwa. W końcu parlament postanowił rozwiązać tę sprawę. W dniu 9 grudniu 2016 r. Zgromadzenie Narodowe Korei Południowej w XX kadencji 234 głosami ${ }^{68}$ uchwaliło impeachment wobec prezydent Park Geun-Hye ${ }^{69}$. Sprawa, tak jak dwanaście lat wcześniej, została przekazana do Trybunału ${ }^{70}$. Parlament zarzucił prezydent przede wszystkim, $\dot{z} \mathrm{e}^{71}$ :

65 Trybunał ocenił, że prezydent też jest urzędnikiem na podstawie ustawy o urzędnikach państwowych.

66 Ciekawe było to, że w 2004 r. prezydent Park była posłanką Zgromadzenia Narodowego. Brała też udział w głosowaniu nad uchwaleniem impeachmentu prezydenta Roh Mu Hyeon. Nie przypuszczała chyba wtedy, że będzie ona na miejscu prezydenta Roh.

67 Https://www.youtube.com/watch?v=ZjUlP4bRjUo.

68 W tym czasie Zgromadzenie Narodowe liczyło 300 posłów.

69 Https://www.nytimes.com/2016/12/22/world/asia/south-korea-president-park-impeachment.html.

70 W tym czasie Konstytucja Korei nie była nowelizowana.

71 Parlament w skardze umieścił 13 zarzutów przeciwko prezydent Park, a Trybunał ograniczył je do 5 zarzutów. 
- dopuściła osobę fizyczną, do tego nieuprawnioną, do swojego urzędu, pozwoliła jej prowadzić politykę państwa i umożliwiała wynoszenie z pałacu prezydenckiego dokumentów państwowych, które były chronione tajemnicą państwową,

- utworzyła fundację sportową, która miała wspierać rozwój sportu w kraju, przy czym celowi temu służyły prywatne pieniądze wielkich koncernów koreańskich (np. koncernu Samsung), a prezydent użyła swojej władzy, naciskając na wybrane firmy, w celu pozyskania odpowiednich funduszy; ponadto oskarżono ją, że zbierała pieniądze w celu prywatnym, czyli uzyskane - według parlamentu - wpłaty miały charakter nienależnych środków pieniężnych (łapówki), z których mogła korzystać Choi Soon Shil’a (Choi Seo Won), za zgodą prezydent Park,

- nie starała się uratować obywateli koreańskich w czasie katastrofy promu Sewol w dniu 16 kwietnia $2014 \mathrm{r}^{72}$.

Trybunał rozpatrywał sprawę do marca 2017 r., czyli blisko cztery miesiące. W tym okresie Trybunał przesłuchał wielokrotnie każdą ze stron. W dniu 10 marca 2017 r. $^{73}$ Trybunał Konstytucyjny wydał decyzję w sprawie impeachmentu pani prezydent Park Geun-Hye. Ostatecznie Trybunał postanowił usunąć z urzędu prezydent Park. W składzie sędziowskim brało udział 8 sędziów ${ }^{74}$ i wszyscy $\mathrm{z}$ nich byli za usunięciem jej z urzędu. Porównując to $\mathrm{z}$ sytuacją sprzed dwunastu lat, Trybunał postąpił nieco inaczej, gdyż ujawnił w swoim uzasadnieniu zdania poszczególnych sędziów, co przedtem nie miało miejsca. Powodem tego była nowela do ustawy o Trybunale Konstytucyjnym ${ }^{75}$. Trybunał uznał, że prezydent Park dopuściła osobę Choe Soon Shil (Choe Seo Won) do urzędu prezydenta, pozwalając jej zabrać dokumenty państwowe. Ponadto Trybunał ocenił, że stanowiło to nieprzestrzeganie konstytucji oraz ustawy o urzędnikach państwowych $^{76}$. W związku z drugim zarzutem Trybunał ocenił, że prezydent Park uzyskała korzyści majątkowe (łapówki) od koncernów, nadużywając swojej władzy, tytułem funduszy publicznych. Organ ten stwierdził, że jest to naruszenie prawa do własności prywatnej tych firm, która jest chroniona przez konstytucję Korei. W przypadku trzeciego zarzutu Trybunał oddalił skargę, gdyż ocenił, że choć samo wydarzenie było tragiczne w skutkach, to nie można oskarżać prezydenta

72 Https://wiadomosci.onet.pl/swiat/katastrofa-koreanskiego-statku-to-ostatnia-szansa-by-powiedziec-ze-cie-kocham/pggde.

73 W tym dniu wydano decyzję w sprawie impeachmentu prezydent Park.

74 W składzie miało być 9 sędziów, przy czym Prezes Trybunału zakończył swoją kadencję. Dlatego Trybunał był zmuszony orzekać w takim składzie sędziowskim.

75 Na podstawie ustawy nr 10546 z 5 kwietnia 2011 r., z częściową zmianą, 법률 제 10546호, 2011. 4. 5., 일부개정.

76 Ustawa nr 14183 z 29 maja 2016 r., zmieniona przez inną ustawę, 법률 제14183호, 2016. 5. 29., 타법개정. 
o to, że nie udało się uratować ofiar tej katastrofy. Dodatkowo Trybunał stwierdził, że prezydent Park nie miała zamiaru przestrzegać konstytucji, ponieważ nie stawiła się osobiście w czasie rozpraw przed Trybunałem, i aż do wydania decyzji Trybunału prawie w ogóle nie komentowała sprawy.

Wynika z tego, że Trybunał uznał, iż jeżeli dany polityk czy też wysoki urzędnik państwowy nie przestrzega prawa, to może zostać usunięty ze stanowiska. Po usunięciu pani prezydent w Korei zostały zorganizowane nowe wybory prezydenckie, na podstawie art. 68 Konstytucji $^{77}$, a nowym prezydentem Republiki Korei został Moon Dze- $\operatorname{In}^{78}$.

\section{Podsumowanie}

Problematyka odpowiedzialności konstytucyjnej władzy wykonawczej należy do istotnych zagadnień ustrojowych wielu państw. W drodze ewolucji instytucji ustrojowych tzw. delikty konstytucyjne znalazły się w kognicji specjalnie powołanych do tego organów, zwykle w postaci trybunałów, choć pierwotnie sprawy takie należały do atrybucji władzy ustawodawczej. Na przykładzie instytucji impeachmentu w praktyce ustrojowej Korei Południowej można zauważyć przenikanie wpływów ustrojowych państw zachodnich na kontynent azjatycki. W szczególności chodzi o rozwiązania zastosowane w konstytucji Stanów Zjednoczonych ${ }^{79}$, ale także w konstytucji Republiki Włoskiej ${ }^{80}$. Warto bowiem zaznaczyć, że podobnie jak w Korei w sprawach odpowiedzialności konstytucyjnej orzeka, w ostatnim z wyżej wymienionych państw, Trybunał Konstytucyjny. Egzemplifikacją tego jest orzeczenie wydane w 1979 r. wobec b. ministra obrony Mario Tanassiego, który był oskarżony o branie łapówek od koncernu Lockeed, i został skazany na dwa lata i cztery miesiące więzienia, grzywnę oraz zakaz pełnienia funkcji publicznych przez dwa i pół roku. Ponadto zostali skazani czterej inni oskarżeni, pełniący wysokie stanowiska w administracji wojskowej, w tym szef sztabu generalnego wojsk powietrznych ${ }^{81}$.

Można przyjąć, że w wyniku tych wydarzeń nastąpiła recepcja rozwiązań ustrojowych innych państw do systemu państwowego Korei, która od 1948 r.

77 Przepis ten stanowił, że kiedy zostanie opróżnione stanowisko prezydenta przed zakończeniem jego kadencji (np. w wyniku śmierci prezydenta w czasie jego kadencji), to w ciągu 60 dni muszą się odbyć nowe wybory prezydenckie.

78 Https://www.tvn24.pl/wiadomosci-ze-swiata,2/korea-poludniowa-mun-dze-in-zostal-zaprzysiezony-na-prezydenta,738465.html.

79 Zob. R. Piotrowski, Senat Stanów Zjednoczonych, op. cit.

80 Zob. Z. Witkowski, System Konstytucyjny Włoch, Warszawa 2000.

${ }_{81}$ Zob. J. Zakrzewska, Ustrój polityczny Republiki Włoskiej, Warszawa 1980, s. 184-185; M. Pietrzak, Odpowiedzialność konstytucyjna, op. cit., s. 50; P. Sarnecki, Ustroje konstytucyjne, op. cit., s. 163. 
była państwem posiadającym konstytucję, chociaż normy tej konstytucji nie były realizowane w praktyce, czego egzemplifikacją jest właśnie stosowanie instytucji impeachmentu w praktyce ustrojowej. Było to związane z ówczesną sytuacją polityczną i sprawowaniem rządów przez czynniki wojskowe. Dopiero w XXI wieku dwukrotnie została zastosowana procedura impeachmentu wobec prezydentów Korei. Zwłaszcza w drugim przypadku zaznaczyła się rola, jaką w całej procedurze pełnił Trybunał Konstytucyjny, który ostatecznie usunął głowę państwa koreańskiego z zajmowanego stanowiska. Na zakończenie należy podkreślić, że Trybunał wydając orzeczenia o impeachmencie, udowodnił, że jest też strażnikiem konstytucji w Korei, tzn. stanowi organ rozstrzygający o fakcie nadużycia władzy przez egzekutywę. Co istotne, procedura impeachmentu w praktyce ustrojowej Korei przebiegała zgodnie z obowiązującymi regulacjami prawnymi, stanowiąc wzór dla innych państw tego regionu.

\section{Bibliografia}

Banaszak B., Porównawcze prawo konstytucyjne współczesnych państw, Warszawa 2007.

Baran K., Dzieje przestępstw politycznych w Anglii między średniowieczem a współczesnością, Kraków 2000.

Baran K., Impeachment a początki odpowiedzialności politycznej ministrów w Anglii, „Zeszyty Naukowe Uniwersytetu Jagiellońskiego. Prace Prawnicze” 1971, z. 51.

Choi S., Władza wykonawcza w Republice Korei, Warszawa 2018.

Dziak W.J., Strnad G., Republika Korei. Zarys ewolucji systemu politycznego, Warszawa 2011.

Esmein A., Prawo konstytucyjne, Warszawa 1921.

Garlicki L., Charakter ustrojowy nowych trybunałów, „Państwo i Prawo” 1986, z. 3.

Gdulewicz E., Kręcisz W., Skrzydło W., Zakrzewski W., Ustroje państw współczesnych, Lublin 1992.

Gubiński A., Trybunał Stanu, „Państwo i Prawo” 1982, z. 5-6.

Jaskiernia J., Zagadnienie podstaw do wszczęcia procedury impeachmentu, „Ruch Prawniczy, Ekonomiczny i Socjologiczny" 1975, nr 4.

Komarnicki W., Polskie prawo polityczne. Geneza i system, Warszawa 1922.

Komarnicki W., Ustrój państwowy Polski współczesnej. Geneza i system, Wilno 1937.

Konstytucja Republiki Korei, przekład z języka koreańskiego A. Diniejko, wprowadzenie i konsultacja merytoryczna M.M.Wiszowaty, Gdańsk 2015.

Konstytucja Stanów Zjednoczonych Ameryki, tłum. i wstęp A Pułł, Warszawa 2002

Koranyi K., Powszechna historia państwa i prawa, t. IV, Warszawa 1967.

Kowalska M., Odpowiedzialność członków egzekutywy przed Trybunałem Stanu w III Rzeczypospolitej Polskiej, Lublin 2018.

Kulig A., Stany Zjednoczone Ameryki [w:] Systemy ustrojowe państw współczesnych, red. S. Bożyk, M. Grzybowski, Białystok 2012. 
Makowski A., Instytucja impeachment w Stanach Zjednoczonych, „Państwo i Prawo” 1975, z. 12.

Makowski A., Patusiak L., Impeachment o usuwaniu polityków z urzędu, Warszawa 1999.

Makowski J., Ustrój konstytucyjny Stanów Zjednoczonych Ameryki Północnej, Warszawa 1918.

Małajny R.M., Amerykański model odpowiedzialności konstytucyjnej, „Studia Prawnicze” 1990 , nr 3.

Marshall McCleallan J., Harczuk J., Impeachment i system równowagi sił, Zamość 1999.

Michalak A., Sułkowski J., System konstytucyjny Korei Południowej, Warszawa 2012.

Okolski A., Ustrój państw europejskich i Stanów Zjednoczonych Ameryki Pótnocnej, Warszawa 1887.

Peretiatkowicz A., Państwo współczesne, Poznań 1947.

Peretiatkowicz A., Państwo współczesne z dodatkiem: ustrój polityczny Stanów Zjednoczonych, Poznań 1920.

Pietrzak M., Odpowiedzialność konstytucyjna w Polsce, Warszawa 1992.

Piotrowski R., Senat Stanów Zjednoczonych Ameryki. Struktura i funkcje, Warszawa 2013.

Sagan S., Serzhanova V., Nauka o państwie współczesnym, Warszawa 2013.

Sarnecki P., Ustroje konstytucyjne państw współczesnych, Warszawa 2013.

Strnad G., Południowokoreańska droga do demokracji, Torun 2010.

Sułkowski J., Parlament Korei Południowej, Warszawa 2012.

Szcząska Z., Odpowiedzialność prawna ministrów w państwach konstytucyjnych XVIIIXIX wieku [w:] Wiek XVIII. Polska i świat. Księga poświęcona Bogusławowi Leśnodorskiemu, Warszawa 1974.

Szcząska Z., Odpowiedzialność rządu w Polsce w latach 1775-1792, „Czasopismo Prawno-Historyczne" 1975, t. XXVII, nr 1.

Szeliga Z., Odpowiedzialność parlamentarzystów, Prezydenta, Rady Ministrów oraz jej członków w świetle Konstytucji RP z 2 kwietnia 1997 roku, Lublin 2003.

Wilson W., Ustrój państwowy Anglii, Warszawa 1917.

Wilson W., Ustrój państwowy Stanów Zjednoczonych Ameryki Pótnocnej, Warszawa 1917. Witkowski Z., System Konstytucyjny Włoch, Warszawa 2000.

Trybunat Stanu w PRL, red. Z. Świda-Łagiewska, Warszawa 1983.

Zakrzewski W., Ustrój polityczny Stanów Zjednoczonych Ameryki [w:] E. Gdulewicz, W. Kręcisz, W. Skrzydło, W. Zakrzewski, Ustroje państw współczesnych, Lublin 1992.

Zaleśny J., Odpowiedzialność konstytucyjna. Praktyka III RP, Warszawa 2004.

Zaleśny J., Odpowiedzialność konstytucyjna w prawie polskim okresu transformacji ustrojowej, Toruń 2004. 